\title{
Antioxidant property, haematinic and biosafety effect of Ipomoea batatas lam. leaf extract in animal model
}

\author{
Benjamin Ogunma Gabriel[1] and MacDonald Idu *i]
}

\begin{abstract}
Background: Plant medicine was dated back for decades and has immensely contributed to the health care system in several countries. This present study evaluated in vitro antioxidant, anti-anaemic and biosafety properties of n-hexane leaf extract of Ipomoea batatas $L$. in an animal model. The antioxidant property of the extract was expressed by 1, 1-diphenyl-1-picrylhydrazyl (DPPH) with an appropriate method. The extract was orally administered at graded doses $(125,250$ and $500 \mathrm{mg} / \mathrm{kg}$ body weight) to determine its effect on $40 \mathrm{mg} / \mathrm{kg}$ phenylhydrazine hydrochlorideinduced anaemia in rats at days 1,7 and 14 using a standard protocol. Acute and subacute toxicological evaluations were based on initial behaviour, mortality and histological examination of the organs.

Results: The antioxidant study of the extract showed $60.14 \%$ in the presence of DPPH and ascorbic acid. The haematological parameters ( $R B C, H G B, H C T, M C V, M C H$ and $M C H C$ ) significantly increased at $p$ value $<0.05$ in the treated groups compared with control groups. Specifically, there is a significant increase in the treatment groups, namely red blood cells $(5.93,6.78,6.75)$, haematocrit $(40.75,44.05,44.63)$ and haemoglobin $(13.35,14.70,14.73)$, when compared with untreated control. Also, the results of the myeloid/erythroid ratio of the treated groups (20:40, 21.7: 43.4 ratio) and (23. 3: 46.6 ratio) are compared with (15.0: 25.0 ratio) of $40 \mathrm{mg} / \mathrm{kg}$ phenylhydrazine and 25: 50 normal control of the bone marrow at day 14 . No acute behavioural change or mortality was observed. Histological analysis exhibited normal physiological state of the visceral organs.
\end{abstract}

Conclusions: These findings support the folklore use of Ipomoea batatas L. leaf extract to reduce oxidative stress, treat anaemia and exhibit its safety at the highest doses of $500 \mathrm{mg} / \mathrm{kg}$ body weight.

Keywords: Ipomoea batatas L., Phenylhydrazine hydrochloride, Anti-anaemia, In vitro antioxidant

\section{Background}

Plants having medicinal properties are helpful in herbal practices and can be broadly used to heal several diseases possibly due to their phytoconstituents [1]. Phytochemicals in a plant are natural chemical components present in varying amounts in plant parts (leaves, vegetables and roots), with defence mechanisms to manage several diseases. Sweet potatoes, botanically called Ipomoea batatas L., are one of the earliest plants used by

*Correspondence: mcdonald@uniben.edu

Phytomedicine Unit, Department of Plant Biology and Biotechnology, University of Benin, PMB 1154, Benin City, Edo State, Nigeria traditional healers to treat different illnesses. I. batatas is from the family 'Convolvulaceae', a dicotyledon having two embryonic seed leaves [2]. Ipomoea batatas L. has been indicated to possess a broad folklore relevance in anti-inflammatory, anti-fertility, anti-carcinogenesis, anti-mutagenicity and anti-diabetes properties, including promoting stable blood sugar levels; they are rich in polyphenols such as caffeoylquinic acid derivatives [3].

On the other hand, anaemia is known to be a global health crises affecting both developed and developing nations. The World Health Organization defines it as a state where several red blood cells or their oxygencarrying capacity (haemoglobin) is not being sufficient 
to meet physiologic needs with respect to age and lifestyle habits such as smoking, sex and pregnancy status [4]. Studies have reported annual cases as high as $19.7 \%$ of anaemia in children, with rural inhabitants taking the more significant proportion [5, 6]. Anaemia is classified into various types, and haemolytic anaemia is one of its kind $[7,8]$. Currently, several studies have shown that $I$. batatas exhibit antioxidative or radical-scavenging phytochemicals with health-enhancing activity in humans [3-5]. Also, evidence has shown that sweet potatoes possess a pivot antioxidant property because of their high quantity of flavonoids, phenols, $\beta$-carotene, anthocyanins and caffeoylquinic acid derivatives [6]. These constituents have been implicated in the correction of heart abnormalities [7]. It is believed that mucilage present in them might be responsible for their antioxidant effects against hydroxyl and peroxyl radicals [9] as much as alternate remedies have great potential in treating illness. Plants with toxic compound can result in organ damage and death. This study therefore evaluates the biosafety, antianaemic and in vitro antioxidant property of Ipomoea batatas L. leave extract.

\section{Methods}

\subsection{Collection of plant material}

Sweet potatoes leaf (Ipomoea batatas L.) was collected from Bolorunduro village Akure, in Ondo State, Nigeria, identified and authenticated by Dr. O. Timothy of the Department of Plant Biology and Biotechnology, University of Benin, Edo State, Nigeria, with voucher number UBH-B473.

\subsection{Preparation of plant material}

The leaves were rinsed and air-dried for three days, after which oven-dried at $40{ }^{\circ} \mathrm{C}$ for few hours. The crunchy leaves were reduced to powder using an electrically powered engine. The powdered sample was stored in a moisture-free, airtight container until further use.

\subsection{Determination of total antioxidant activity}

The antioxidative activity of the plant extract was studied as the free radical-scavenging effect on the 2, 2-diphenyl1-picrylhydrazyl radical and determined by UV spectrophotometry at $517 \mathrm{~nm}$. Radical scavenging activity was measured by a slightly modified method previously described by Dini et al. [6], using $20-100 \mu \mathrm{g} / \mathrm{ml}$ of the crude extract and ascorbic acid prepared in methanol (analytical grade). After that, $1 \mathrm{ml}$ of the plant extract was placed in a test tube, with $2 \mathrm{ml}$ of $0.1 \mathrm{Mm}$ DPPH in methanol. A control solution was prepared to contain the same amount of methanol and DPPH. The radical scavenging activity was calculated using the following formula.

$$
\% \text { inhibition }=\left(A_{\mathrm{a}}-A_{\mathrm{a}} / A_{\mathrm{b}}\right) \times 100
$$

where $A_{\mathrm{b}}$ is the absorption of the blank sample and $\mathrm{Aa}$ is the absorption of the plant extract.

\subsection{Experimental animals}

Fifty-four (54) male albino rats weighing between 180 and $250 \mathrm{~g}$ were obtained from the animal house of the Pharmacology Department, University of Benin, Benin City. They were housed in conducive cages and allowed free access to rat chow and water and acclimatize for two weeks. The animals were handled according to standard protocols for the use of laboratory animals approved by the ethical committee of the Faculty of Life Sciences with ethical number LS17101.

\subsection{Experimental design}

Six (6) groups labelled A-F were designed for this study, each group having nine (9) rats housed in separate cages. Groups A, B, D, E and F were induced with $40 \mathrm{mg} / \mathrm{kg}$ phenylhydrazine hydrochloride for five (5) days orally, while group $\mathrm{C}$ was given distilled water alone. The animals were post-treated with oral administration of distilled water, $5 \mathrm{mg} / \mathrm{kg}$ ferrous (iii) hydroxide poly-maltose or groups A and B and 125, $250 \mathrm{mg} / \mathrm{kg}$ and $500 \mathrm{mg} / \mathrm{kg}$ n-hexane plant extract for groups $\mathrm{D}, \mathrm{E}$, and $\mathrm{F}$, respectively, for days 1, 7 and 14 . The rats' body mass indexes were taken and recorded every week.

\subsubsection{Haematology assays}

Three (3) millilitres of blood was collected from each group at days 1, 7 and 14 into 5-ml EDTA tubes by cardiac puncture using syringes and needles. The haematological analysis was done almost immediately using an automatic haemato-analyzer (Sysmex, KX-21, Japan). The parameters measured included red blood cells (RBCs), haemoglobin (HGB), haematocrit (HCT), mean corpuscular volume $(\mathrm{MCV})$, mean corpuscular haemoglobin $(\mathrm{MCH})$ and mean corpuscular haemoglobin concentration $(\mathrm{MCHC})$.

\subsubsection{Peripheral blood film}

The slides were cleaned with $70-90 \%$ alcohol and allowed to air dry. The middle or ring finger was selected to make a hole. The area was washed with $70 \%$ ethyl alcohol and punctured. A drop of blood was touched to the clean slide. Blood was spread on the glass slide by another slide. It was repeated with several slides. Slides were dried and fixed with methanol. Photomicrographs were taken at $\times 40$ using a digital camera. 


\subsubsection{Bone marrow preparation}

Bone marrow from the femur bones was isolated and fixed in $10 \%$ (vol/vol) formaldehyde, cleaned up in xylene and decalcified to be embedded in a paraffin wax (melting point at 56\%) according to the method of Ogwumike [10] and stained with eosin/haematoxylin. Photomicrographs were taken at $\times 40$ using a digital camera.

\subsection{Acute toxicity study}

Determination of acute toxicity was performed using a modified method by Lorke [11] and class method in adherence to the Organization for Economic Cooperation and Development (OECD) Guideline for Testing Chemicals No. 423 OECD, [12]. This was performed in two phases. In phase 1 , forty-five (45) mice were randomly divided into nine (9) groups of five (5) each. Ipomoea batatas $\mathrm{L}$. $\mathrm{n}$-hexane leaves extract was administered in single dose of 10,100 and $1000 \mathrm{mg} / \mathrm{kg}$ ) orally. Observable toxicological signs were recorded. With the absence of toxicity, the second phase experimented. Based on the acquired results from phase 1 , phase 2 is scheduled with three (3) mice per group administered a single dose $(1600,2,900$ and $5,000 \mathrm{mg} / \mathrm{kg})$ of $I$. batatas $\mathrm{n}$-hexane leaves extract orally. The animals in both phases were kept under the same conditions and observed for general behaviour changes continuously for $30 \mathrm{~min}$, every hour during the first $24 \mathrm{~h}$ and at least once daily for 14 days after administration of the extract. Observations were focused on parameters such as piloerection, sensitivity to sound and touch, locomotion, aggressiveness, the appearance of faeces, salivation, urinating, convulsing, coma and death. The number of survivors was noted after $24 \mathrm{~h}$. Animals' weights were observed for days 0,7 and 14 . The $\mathrm{LD}_{50}$ was evaluated and classified according to the Globally Harmonized System (GHS) for the classification of chemicals $[12,13]$. The $\mathrm{LD}_{50}$ was calculated based on the final results in the square root of the product of the lowest lethal dose and the highest non-lethal dose, i.e. the geometric mean of the consecutive doses, where 0 and $100 \%$ survival rates were recorded.

Every rat used in the acute toxicity study experimented daily for possible toxicity signs over two weeks.

The $\mathrm{LD}_{50}$ is calculated using the formula:

$$
\mathrm{LD}_{50}=\sqrt{\left(D_{0} \times D_{100}\right)}
$$

$D_{0}=$ Highest dose that gave no mortality, $D_{100}=$ Lowest dose that produced mortality.

\subsection{Histological study}

The organs (liver, kidney, heart and spleen) were fixed in $10 \%$ (vol/ vol) formaldehyde, cleaned up in xylene and embedded in a paraffin wax (melting point at 56 percent). Tissue sections were prepared according to Drury and Wallinton [14] and stained with eosin/haematoxylin. Photomicrographs were taken at $\times 400$ using a digital camera.

\subsection{Statistical analysis}

Data were presented as mean \pm SEM of the respective replicates. Means of different groups were compared using ANOVA using GraphPad prism version $6 \mathrm{com}$ puter software packages. P values $\leq 0.05$ (95\% confidence interval) were considered significant.

\section{Results}

\subsection{Antioxidant}

The results of the total antioxidant activity of n-hexane extract of Ipomoea batatas L. are indicated in Fig. 1 . The

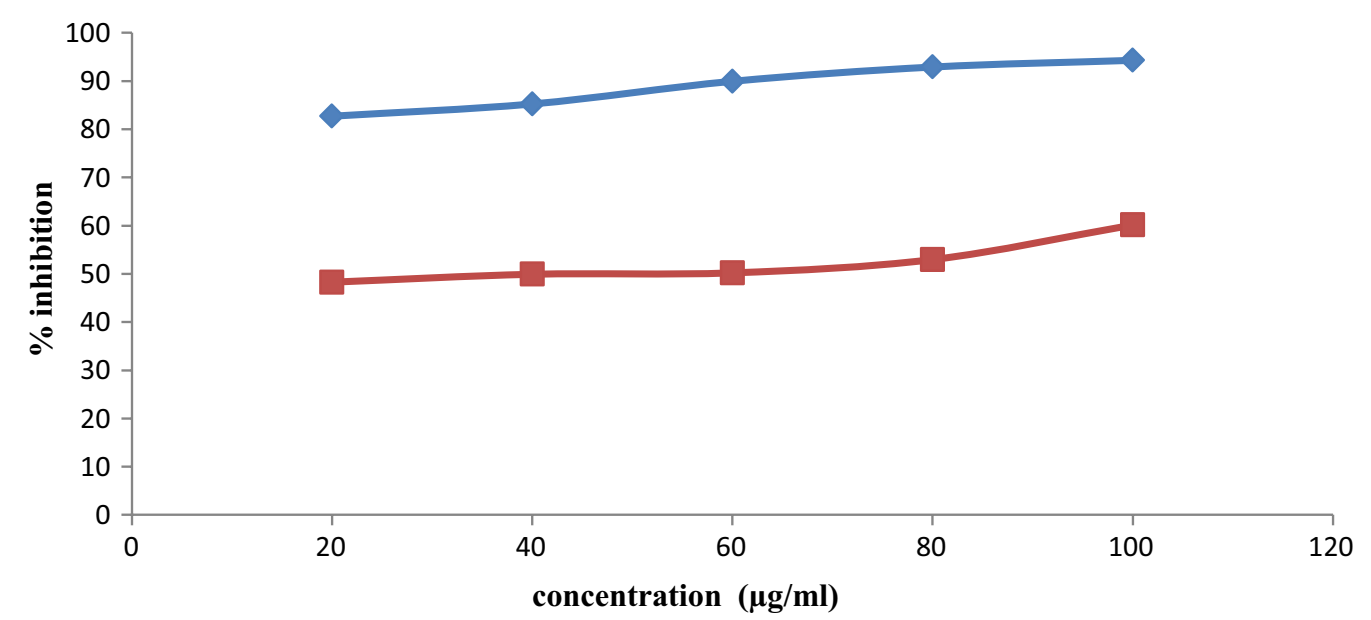

Fig. 1 DPPH scavenging activities of crude n-hexane extracts of Ipomoea batatas L. leaves. Blue —day 1, Red_day 7, Orange-day 14. Blueascorbic acid, Red-I. batatas 
n-hexane extract was observed to possess the highest free radical scavenging potential with percentage inhibition of $39.21 \pm 1.70 \%$ at $100 \mu \mathrm{g} / \mathrm{ml}$ when compared with the standard (ascorbic acid) $89.02 \pm 2.21$ at $100 \mu \mathrm{g} / \mathrm{ml}$.

\subsection{Anti-anaemic study}

Figure 2 shows a significant decrease in red blood cell count across groups A, B, D, E and F on day 1 of the experiment with a subsequent increase on day 7 and a significant increase on day 14 of the investigation after treatment with $\mathrm{n}$-hexane leaves extract of $I$. batatas. Figure 3 also shows a significant decrease in packed cell volume across groups A, B, D, E and F on day 1 of the experiment with subsequent increase on days 7 and 14 after treatment with n-hexane leaves extract of $I$. batatas. Our results also showed a significant decrease in

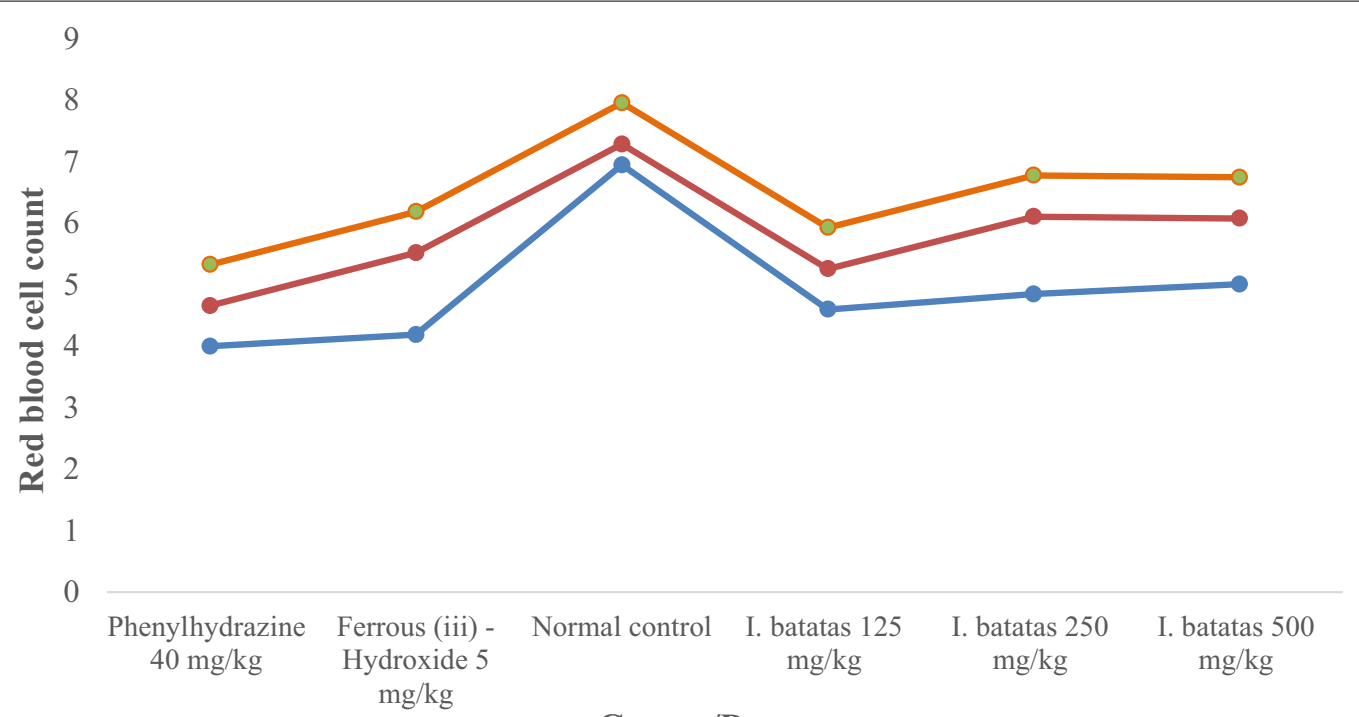

Groups/Doses

Fig. 2 Effect of n-hexane leaves extract of Ipomoea batatas on red blood cell count in rats. Blue—day 1, Red—day 7, Orange—day 14

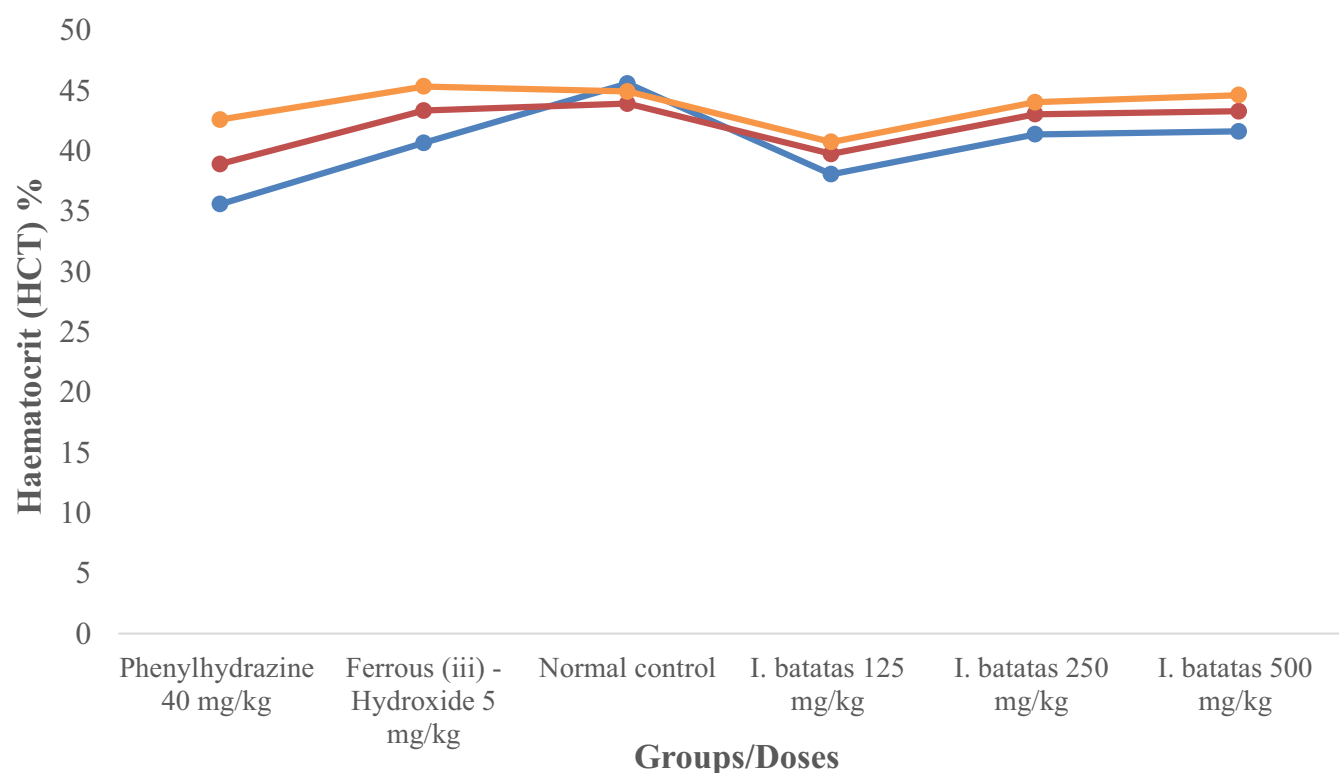

Fig. 3 Effect of Ipomoea batatas L. n-hexane leaves extract on haematocrit (HCT) \% in the phenylhydrazine-induced anaemic rats. Blue-day 1 , red-day 7 , orange-day 14 
haemoglobin across groups A, B, D, E and F on day 1 of the experiment with subsequent increase on day 14 of the experiment after treatment with $\mathrm{n}$-hexane leaves extract I. batatas in Fig. 4.

Similarly, Fig. 5 presents the effect of I. batatas n-hexane leaves extract on mean corpuscular volume (MCV) fl in phenylhydrazine-induced anaemia. The results showed a significant decrease in mean corpuscular volume across groups A, B, D, E and F on day 1 of the experiment with a subsequent increase on day 7 with a significant increase on day 14 of the investigation after treatment with n-hexane leaves extract of $I$. batatas. Likewise, Fig. 6 observes

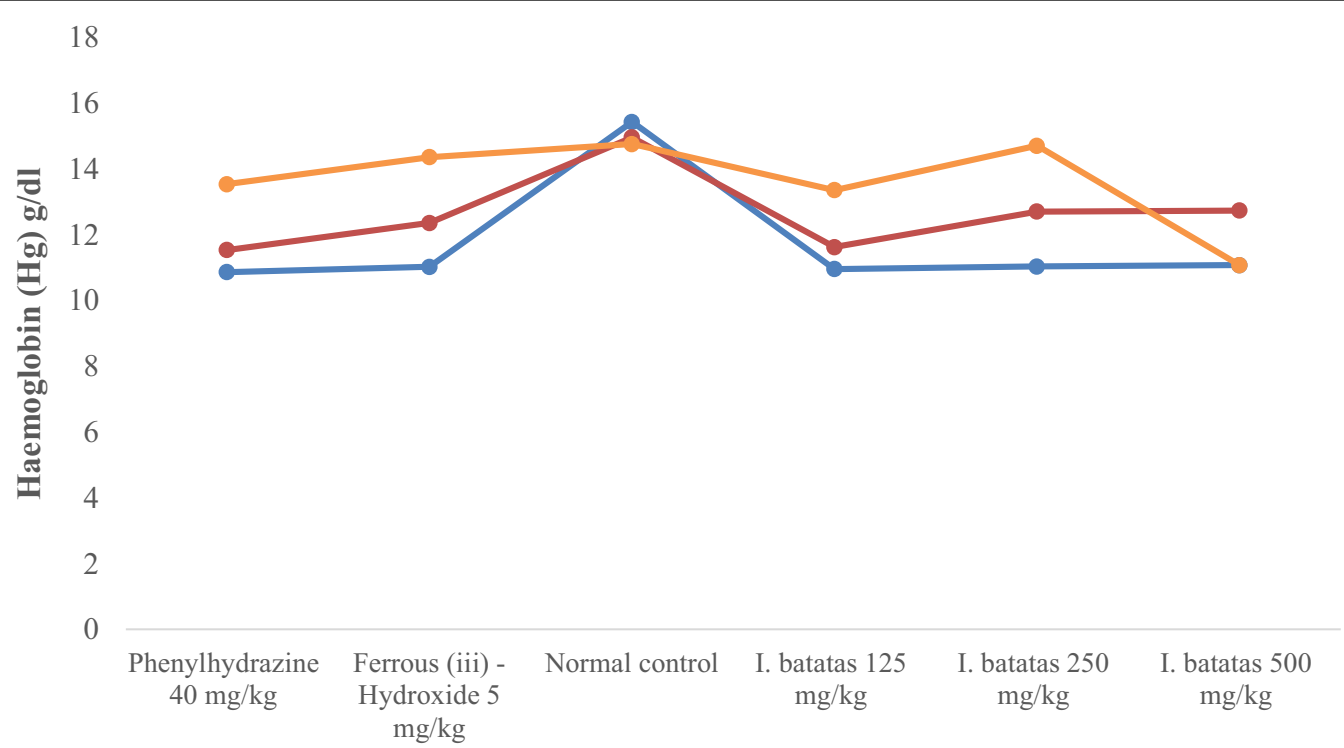

\section{Groups/Doses}

Fig. 4 Effect of Ipomoea batatas L. n-Hexane leaves extract on haemoglobin $(\mathrm{Hg}) \mathrm{g} / \mathrm{dl}$ in phenylhydrazine-induced anaemic rats. Blue - day 1 , red-day 7 , orange—day 14

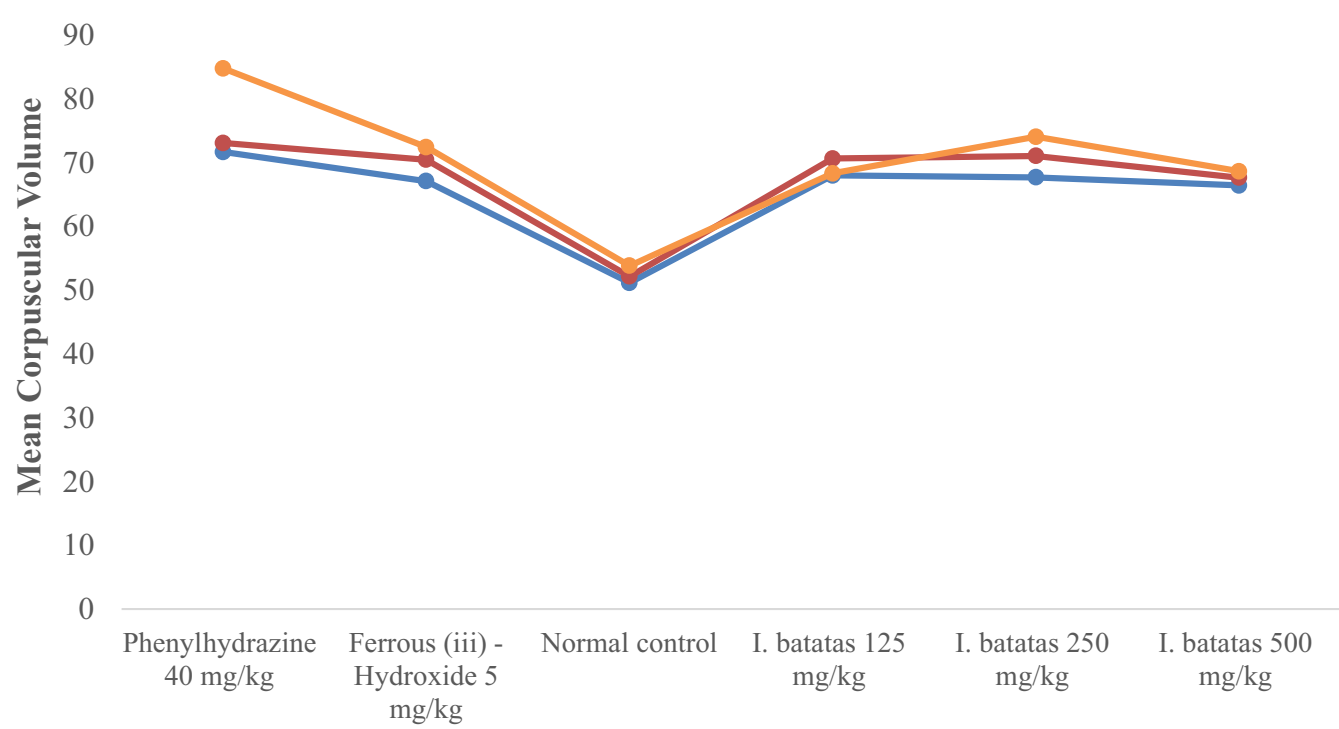

\section{Groups/Doses}

Fig. 5 Effect of Ipomoea batatas L. n-hexane leaves extract on mean corpuscular volume in phenylhydrazine-induced anaemic rats. Blue-day 1, red-day 7 , orange-day 14 


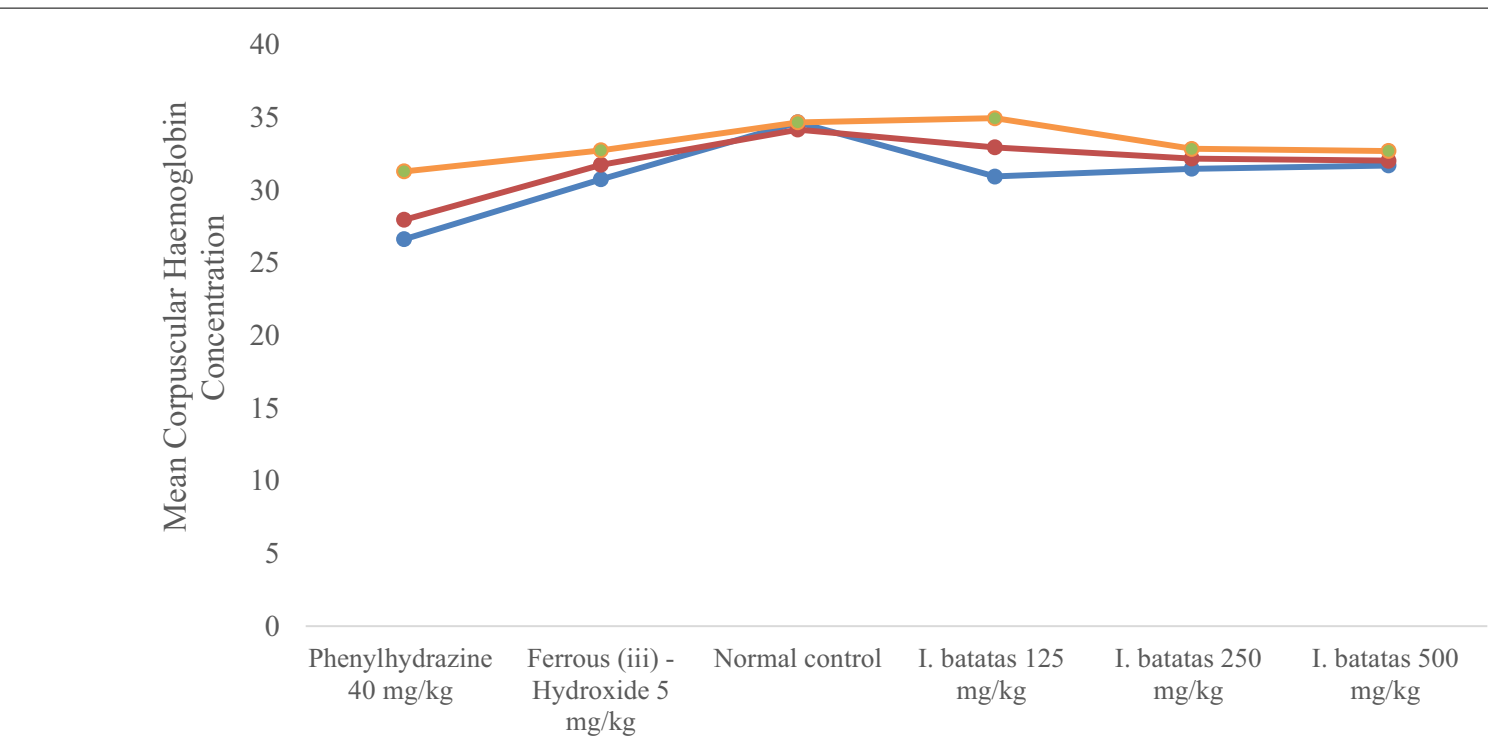

\section{Groups/Doses}

Fig. 6 Effect of Ipomoea batatas L. n-Hexane leaves extract on mean corpuscular haemoglobin concentration in phenylhydrazine-induced anaemic rats. Blue-day 1 , red-day 7 , orange-day 14

a substantial decrease in mean corpuscular haemoglobin concentration (MCHC) across groups $\mathrm{A}, \mathrm{B}, \mathrm{D}, \mathrm{E}$ and $\mathrm{F}$ on day 1 of the experiment with a subsequent increase on days 7 and 14 of the investigation after treatment with n-hexane leaves extract of I. batatas.

Additionally, the effect of $I$. batatas n-hexane leaves extract on mean corpuscular haemoglobin $(\mathrm{MCH}) \mathrm{pg}$ in phenylhydrazine-induced anaemia is presented in Fig. 7.
The results revealed that a similar trend for other parameters was observed with a significant decrease in mean corpuscular haemoglobin concentration across groups A, $B, D, E$ and $F$ on day 1 of the experiment with a subsequent increase on day 14 of the investigation after treatment with $\mathrm{n}$-hexane leaves extract of $I$. batatas.

The result of the study showed that the administration of the graded dose of n-hexane extracts induced

30

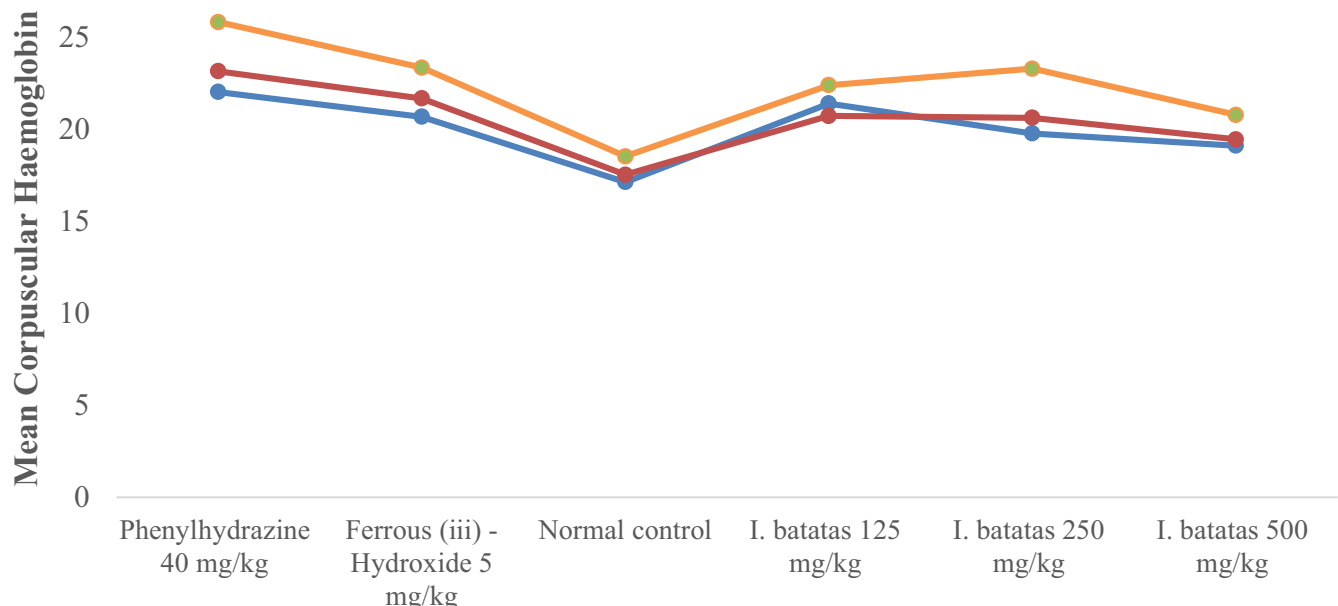

Groups/Doses

Fig. 7 Effect of Ipomoea batatas L. n-Hexane leaves extract on mean corpuscular haemoglobin in phenylhydrazine-induced anaemic rats. Blueday 1 , red-day 7 , orange-day 14 
normochromic and normocytic cells on the damaged red blood cells on day 14. This revealed a strong effect of the extract on red blood cells compared with the group that received $40 \mathrm{mg} / \mathrm{kg}$ phenylhydrazine hydrochloride and $5 \mathrm{mg} / \mathrm{kg}$ of ferrous (iii) hydroxide (Fig. 8).

\subsection{Bone marrow}

The graded doses of $\mathrm{n}$-hexane extract of $I$. batatasinduced myeloid-erythroid cells with a mild increase of 20:40 (M: E ratio) for $125 \mathrm{mg} / \mathrm{kg}, 21.7: 43.4$ (M: E ratio) for $250 \mathrm{mg} / \mathrm{kg}$ and 23.3:46.6 (M: E ratio) for $500 \mathrm{mg} / \mathrm{kg}$ at day 14, when compared with distilled water alone, up to 25: 50 (M: E ratio) which is normal, and less than 14.9: 25.1 (M: E ratio) for $40 \mathrm{mg} / \mathrm{kg}$ phenylhydrazine group showing a severe anaemic condition in rats and $5 \mathrm{mg} /$ $\mathrm{kg}$ of ferrous (iii) hydroxide-induced myeloid-erythroid ratio, all at day 14 (Fig. 9).

\subsection{Acute and subacute study}

The results from the experimental acute toxicity studies revealed that $n$-hexane leaf extracts were safe up to the highest dose of $5000 \mathrm{mg} / \mathrm{kg}$. No lethal signs and symptoms or behavioural changes were observed. Also, no mortality was recorded during the period of the study.

The histological examination of the study showed that administration of graded doses of n-hexane leaf extract of $I$. batatas-induced moderate vascular dilation of the heart compared to graded doses of administered control (distilled water). The study also showed that administration of graded doses of $\mathrm{n}$-hexane extract of I. batatasinduced mild vascular congestion and moderate Kupffer cell activation to the liver while control (distilled water) (Fig. 10).
The effect from n-hexane leaf extract of I. batatas on the spleen (Fig. 11) showed that administration of graded doses of n-Hexane extract of $I$. batatas induced normal follicular architecture on the spleen when compared with the Control (distilled water). The effect of $n$-hexane leaf extract of I. batatas on the spleen, as shown in Fig. 12, displayed graded doses of the treatment groups' induced normal follicular architecture of the spleen compared to the Control (distilled water). Poly-maltose induced severe sinus dilation and mild follicular atrophy on the spleen.

Figure 13 depicts the effect of $n$-hexane leaf extract of $I$. batatas on the kidneys. It showed that the treated groups induced mild interstitial congestion in the kidney compared with the control (distilled water).

\section{Discussion}

The result also showed that Ipomoea batatas L. n-hexane leaf extracts displayed scavenging activities at $39.21 \pm 1.70 \%$ at $100 \mu \mathrm{g} / \mathrm{ml}$ when compared with the standard (ascorbic acid) $89.02 \pm 2.21$. The scavenging property of the extract was more pronounced at the highest concentration, as shown in Fig. 1. The plant extract inhibits oxidation of $\mathrm{DPPH}$, which indicates that it can donate protons and scavenge other stable radicals, given that phenylhydrazine-induced haemolysis could be a result of oxidative stress [15-17].

The study evaluated the anti-anaemic activity of n-hexane leaf extract of I. batatas on $40 \mathrm{mg} / \mathrm{kg}$ phenylhydrazine hydrochloride-induced haemolytic anaemia albino rats. The result of this study showed that haemolytic anaemia was caused using phenylhydrazine hydrochloride [18] intraperitoneally in albino rats, and $I$. batatas extract was orally administered to examine its result
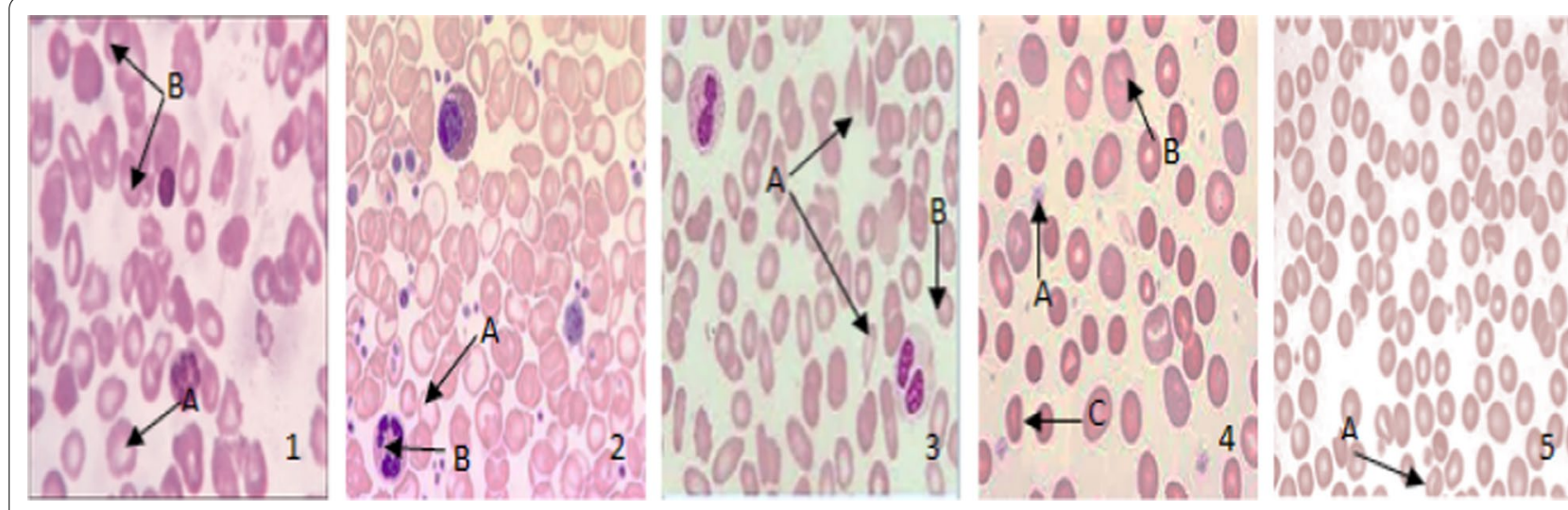

Fig. 8 Effect of $n$-hexane leaf extract of Ipomoea batatas L. on normochromic and normocytic cells. Phenylhydrazine alone A indicates macrocytes. B, hypochromic macrocytes and C platelet; (2) $5 \mathrm{mg} / \mathrm{kg}$ of ferrous (iii) hydroxide A indicates normochromic and normocytic cell, B multi-segmented neutrophil; (3) $125 \mathrm{mg} / \mathrm{kg} \mathrm{n}$-hexane and phenylhydrazine, A, teardrop cell, B, normal red cell; (4) $250 \mathrm{mg} / \mathrm{kg} \mathrm{n}$-hexane and phenylhydrazine,

A, platelet, B, partially hypochromic macrocytic red cell, C, poikilocytes and normocytic cells (5) $500 \mathrm{mg} / \mathrm{kg} \mathrm{n}$-hexane plant extract and phenylhydrazine, A, normochromic and normocytic cells. They were using haematoxylin-eosin dye with X 40 magnification 

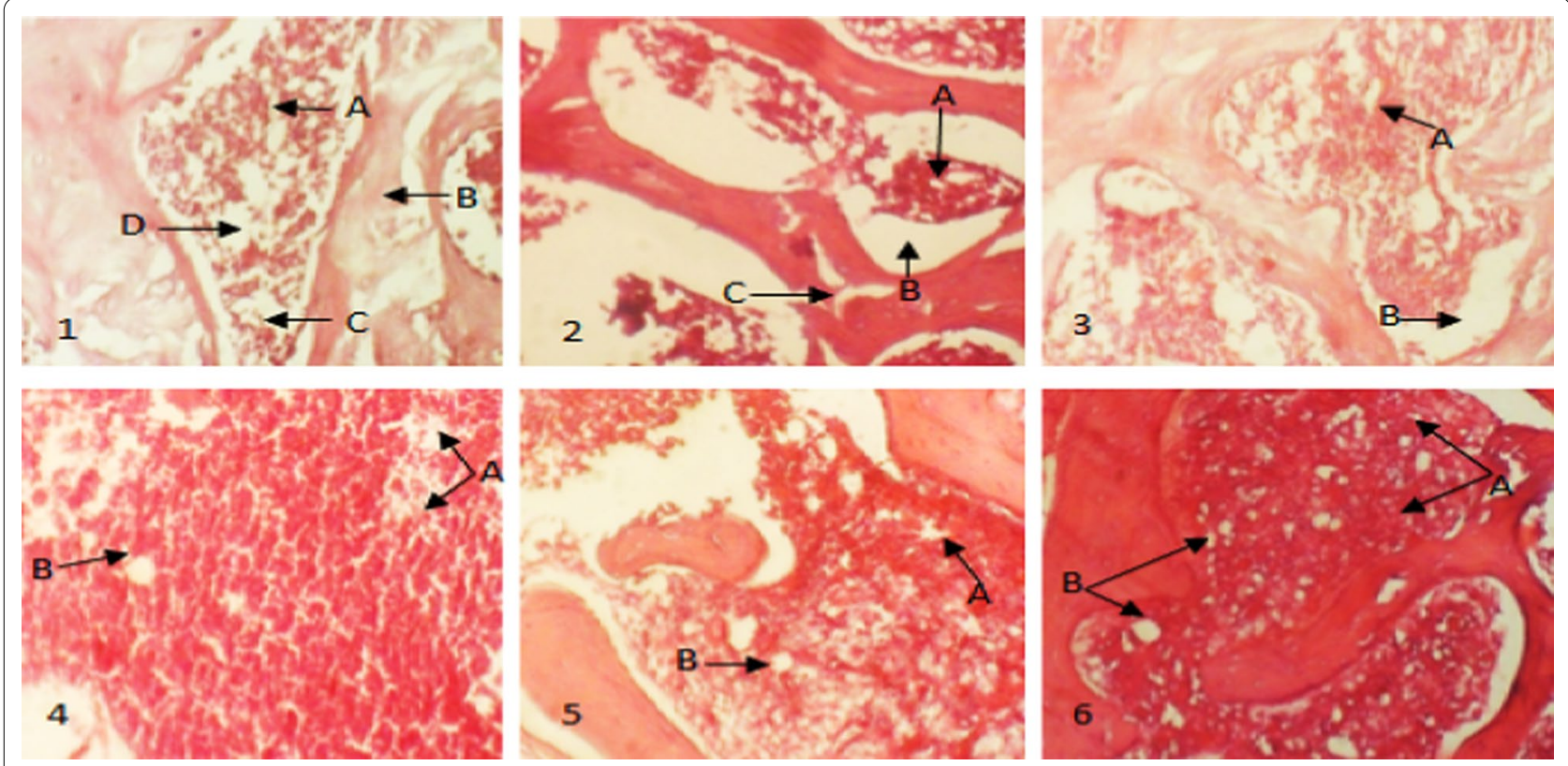

Fig. 9 Effect of $n$-hexane leaf extract of Ipomoea batatas $L$. on myeloid-erythroid cells in albino rats. (1) showed the control rat bone marrow composed of A—megakaryocyte, B—bone, C—-myelo-erythroid cells, and D_fat vacuoles, (2) phenylhydrazine alone showed moderately decreased A—marrow, B — fat ratio and C—bone trabecula, (3) at $5 \mathrm{mg} / \mathrm{kg}$ of ferrous (iii) hydroxide, the results showed normal A—marrow, B - fat ratio, (4) at $125 \mathrm{mg} / \mathrm{kg}$ n-hexane leaf extract, our results showed moderately increased A-marrow, and B-fat ratio (5) at $250 \mathrm{mg} / \mathrm{kg} \mathrm{n}$-hexane leaf extract, the result found a moderately increased A —-marrow and B - fat ratio (6) at $500 \mathrm{mg} / \mathrm{kg} \mathrm{n}$-hexane leaf extract, the result observed a moderately increased A—-marrow and B-fat ratio, using haematoxylin-eosin dye with X 40 magnification
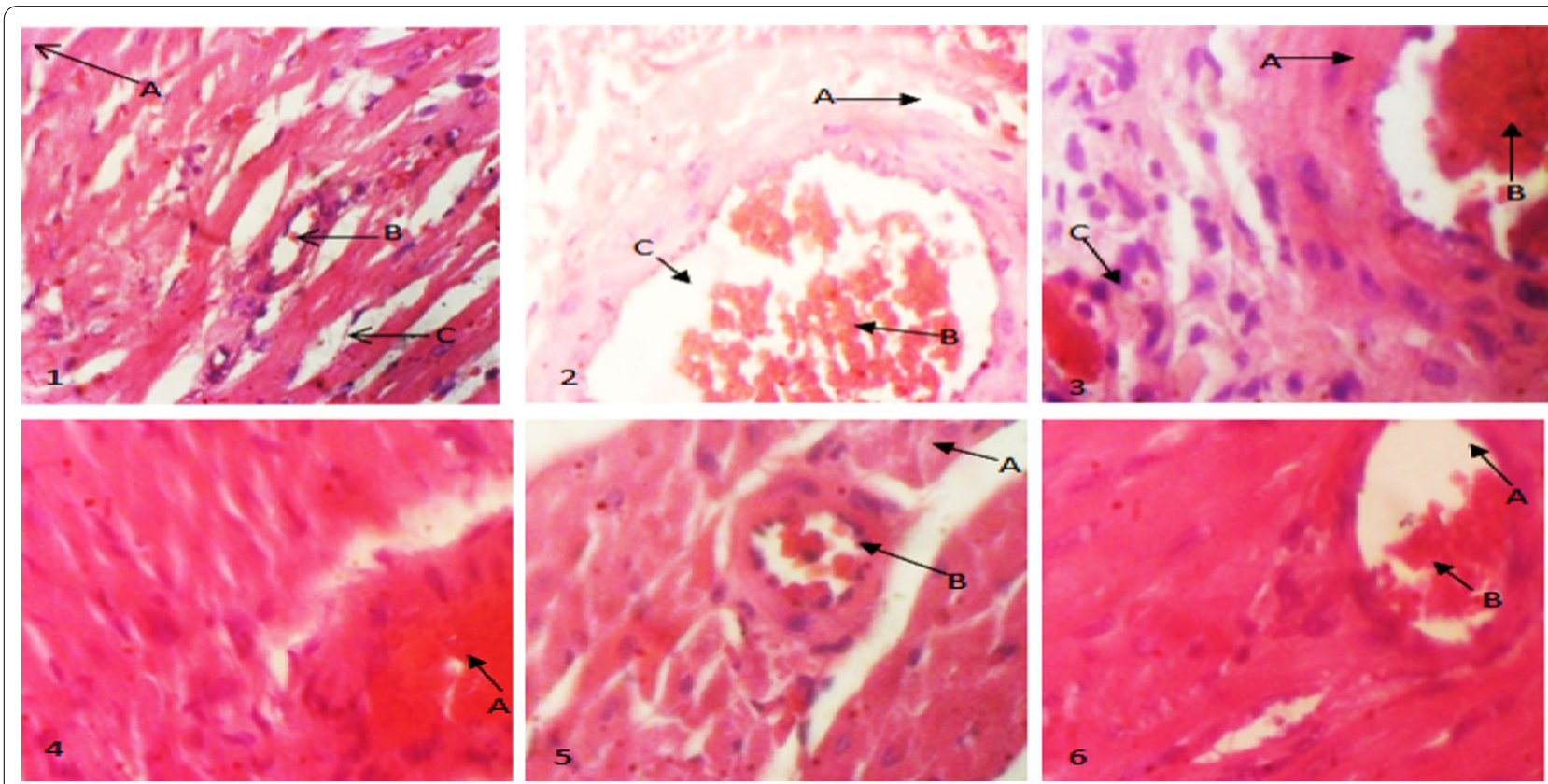

Fig. 10 Effect of $n$-hexane leaf extract of Ipomoea batatas $L$. on the heart. Pic (1) represents control rat heart composed of: A-bundles of myocardial fibres, B - coronary vessel and C - interstitial space, (2) phenylhydrazine alone showed; A — dilated coronary vessel with B - mild vascular congestion, (3) at $5 \mathrm{mg} / \mathrm{kg}$ of ferrous (iii) hydroxide showed; A-dilated coronary vessel, B-mild vascular congestion and C—heavy infiltrates of inflammatory cells, (4) at $125 \mathrm{mg} / \mathrm{kg} \mathrm{n}$-hexane extract showed A-moderate vascular congestion (5) at $250 \mathrm{mg} / \mathrm{kg} \mathrm{n}$-hexane extract showed A—normal my cardiac fibres and B —normal coronary vessel (6) at $500 \mathrm{mg} / \mathrm{kg} \mathrm{n}$-hexane extract showed A—moderate vascular dilation and $\mathrm{B}$-mild congestion. They were using haematoxylin-eosin dye with $X 40$ magnification 

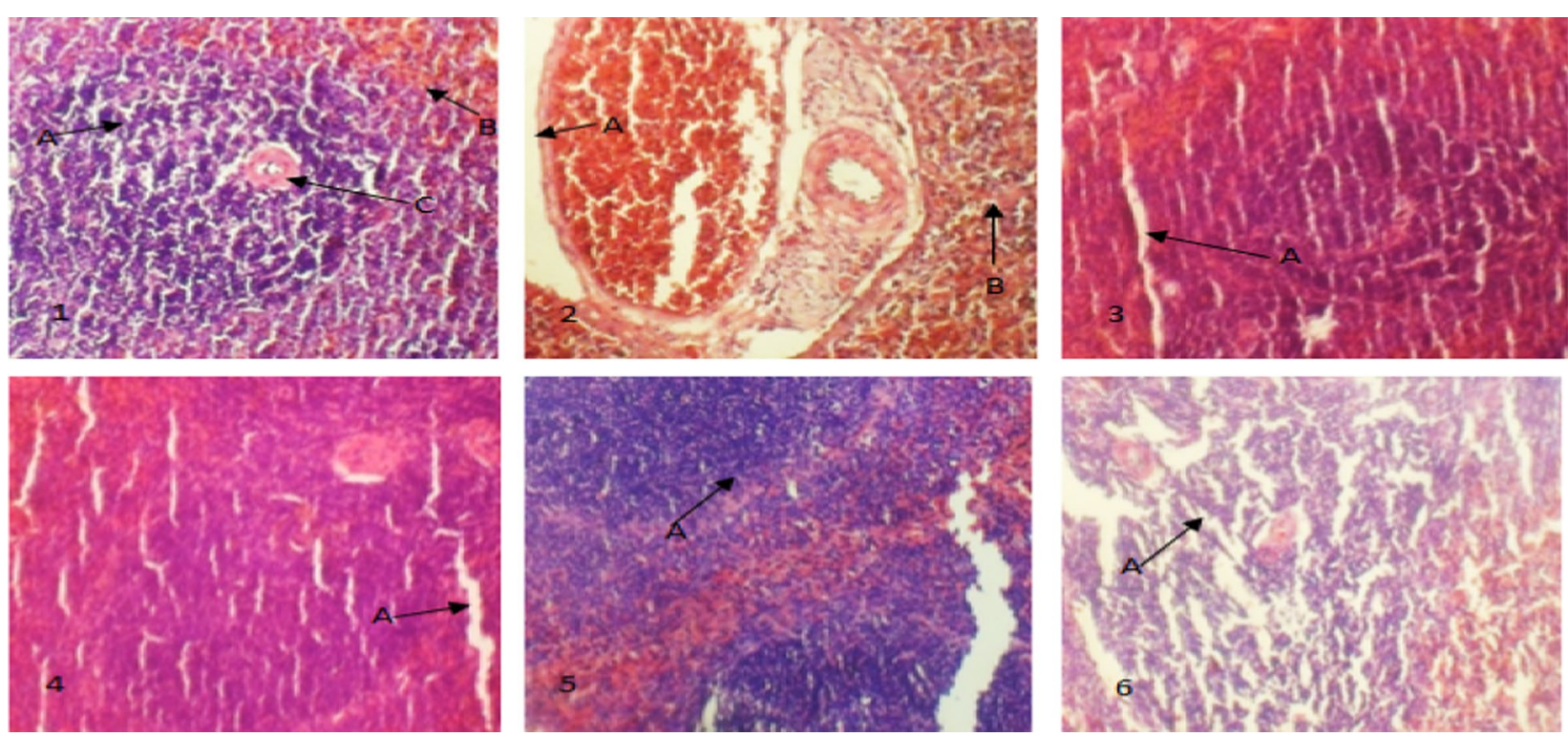

Fig. 11 Effect of $n$-hexane leaf extract of Ipomoea batatas L. on the spleen. (1) The control Rat spleen represented with $A$ as white pulp, B as red pulp and $\mathrm{C}$ as arteriole, (2) phenylhydrazine alone showed A—severe sinus dilation and B-moderate follicular atrophy, (3) at $5 \mathrm{mg} / \mathrm{kg}$ of ferrous (iii) hydroxide poly-maltose showed A—mild follicular atrophy, (4) at $125 \mathrm{mg} / \mathrm{kg}$ n-hexane showed A—normal follicular architecture (5) $250 \mathrm{mg} /$ $\mathrm{kg}$ n-hexane showed A—normal follicular architecture and (6) 500 mg/kg n-hexane showed A—normal follicular architecture. They were using haematoxylin-eosin dye with X 40 magnification
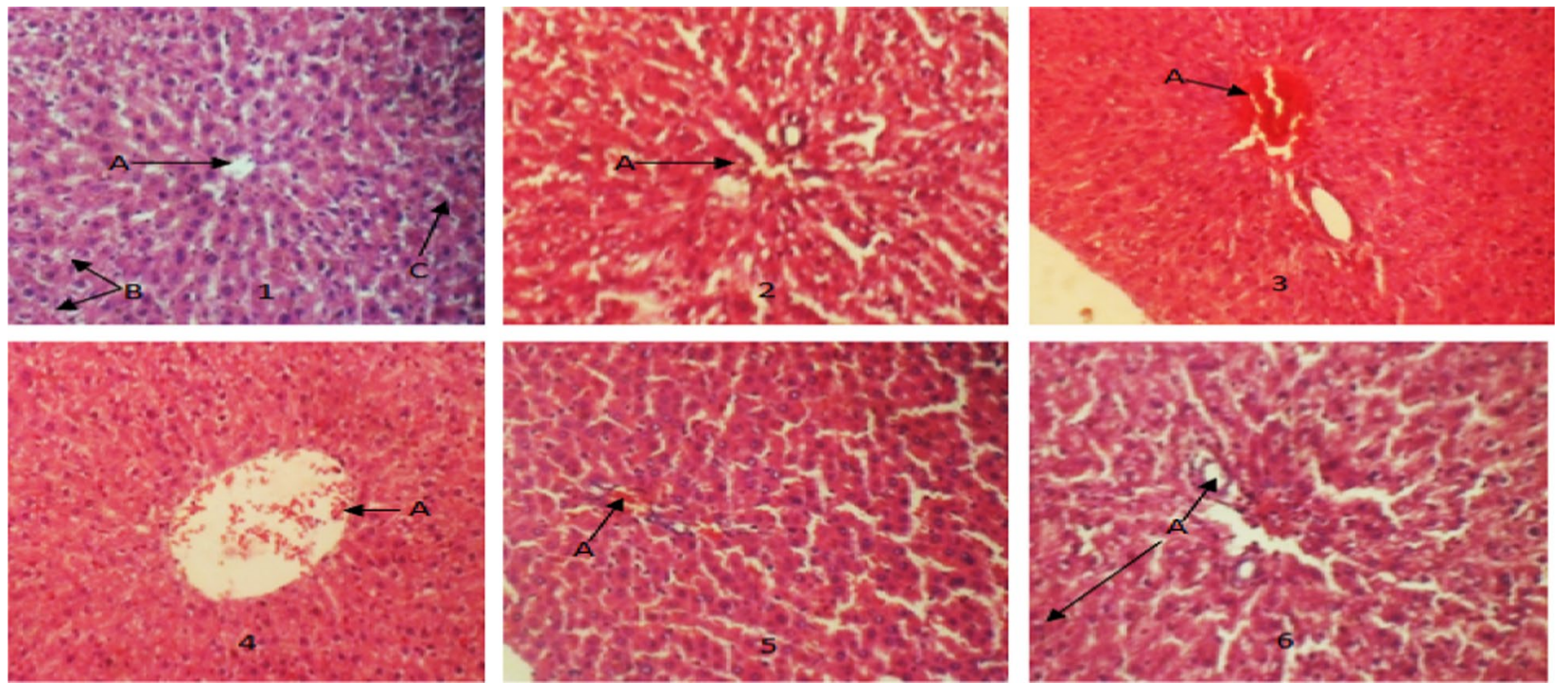

Fig. 12 Effect of $n$-hexane leaf extract of Ipomoea batatas L. on the liver. (1) The control Rat liver composed of A—central vein, B-hepatocytes and C—-sinusoids, (2) Rat liver treated with phenylhydrazine alone showed A—patchy vascular intimal ulceration, (3) rat liver treated with $5 \mathrm{mg} / \mathrm{kg}$ of ferrous (iii) hydroxide poly-maltose showed A-moderate vascular congestion, (4) at $125 \mathrm{mg} / \mathrm{kg} \mathrm{n}$-hexane extract showed mild vascular congestion (5) at $250 \mathrm{mg} / \mathrm{kg} \mathrm{n}$-hexane showed A-mild vascular congestion and (6) at $500 \mathrm{mg} / \mathrm{kg} \mathrm{n}$-hexane extract showed A-normal liver architecture (H\&E $\times 100)$ of hepatocytes. They were using haematoxylin-eosin dye with X 40 magnification

when compared with ferrous (iii) hydroxide (reference drug). The effect of the treated groups was observed by evaluating the haematological index, namely Hgb, HCT,
$\mathrm{RBC}, \mathrm{MCHC}, \mathrm{MCV}$ and $\mathrm{MCH}$, as shown in Figs. 2, 3, 4, 5, 6, 7. The result showed that exposure to phenylhydrazine hydrochloride reduced haemoglobin levels in untreated 


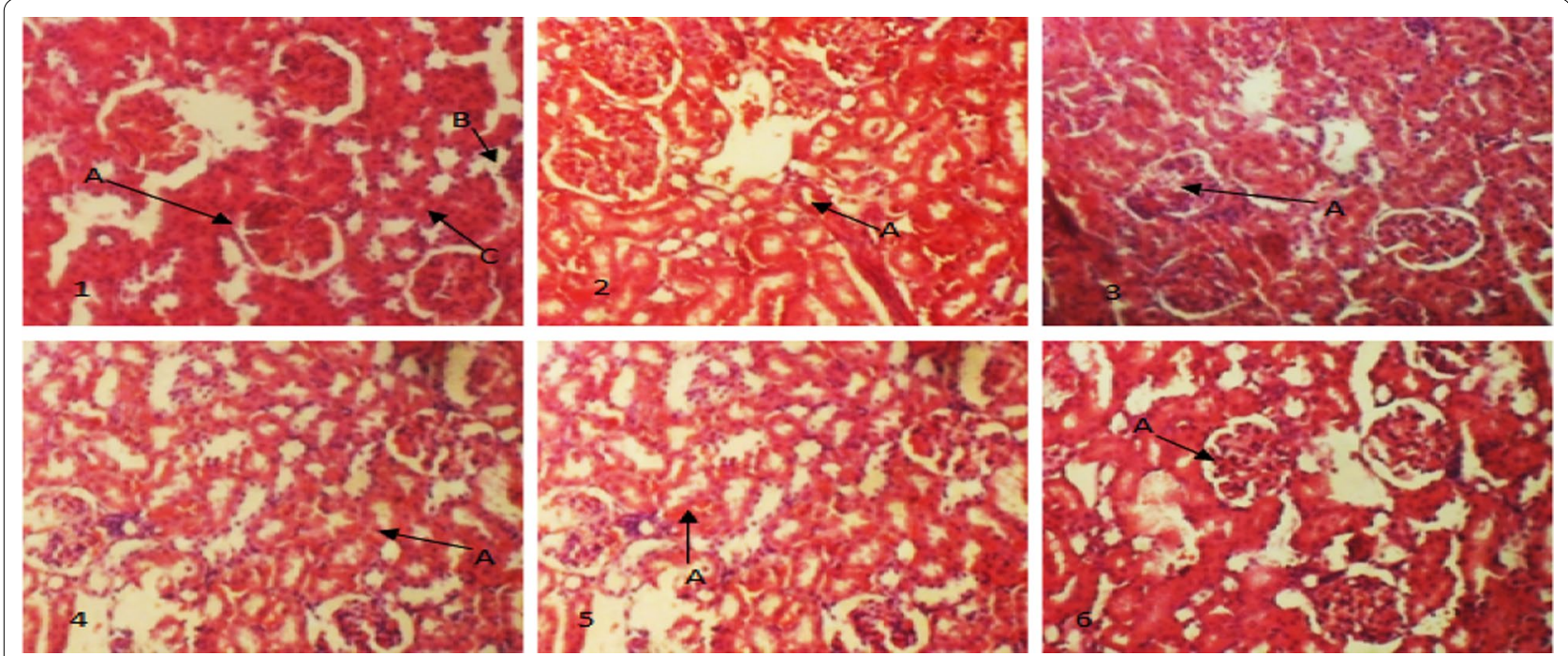

Fig. 13 Effect of $n$-hexane leaf extract of Ipomoea batatas L. on kidney. (1) Control rat kidney composed of A-glomerulus, B -tubules and C-interstitial space, (2) phenylhydrazine administered alone showed A-focal vascular intimal erosion, (3) at $5 \mathrm{mg} / \mathrm{kg}$ of ferrous (iii) hydroxide poly-maltose showed A-mild interstitial congestion, (4) 125 mg/kg n-hexane extract showed A, mild interstitial congestion (5) $250 \mathrm{mg} / \mathrm{kg}$ n-hexane extract showed A, mild interstitial congestion and (6) 500 mg/kg n-hexane extract showed A, normal renal architecture in the kidney. Using haematoxylin-eosin dye with X 40 magnification

rats (Figs. 4 and 6). Anaemia was treated on days 1, 7 and 14 using ferrous (iii) hydroxide and I. batatas n-hexane extract. A similar effect was achieved by Ogwumike [19] anti-anaemia effects of Sorghum bicolor. Also, 125, 250, and $500 \mathrm{mg} / \mathrm{kg}$ of the extract stimulated haemoglobin production and ferrous (iii) hydroxide at day 14. Results from Figs. 2, 3, 4, 5, 6, 7 elicited the effect of n-hexane extract, triggered regeneration of red blood cell, haematocrit, haemoglobin, mean corpuscular volume and mean corpuscular haemoglobin, which is one of the significant markers that depicted anaemia. Specifically, at 250 and $500 \mathrm{mg} / \mathrm{kg}$ of the extracts it showed a better haematinic activity when compared with the anaemia group. This suggested the possible mechanism of action through which the extracts elicit its action, mimicking one of the actions displayed by iron ingestion. This agreed that haemoglobin is found in red blood cells; thereby, the effect from the extract improved their regenerations.

Additionally, it was also observed that there was a significant reduction in red blood cell count in the untreated group (haemolysis). This reduction recompensed the standard value in the treated groups by ferrous (iii) hydroxide and I. batatas extract. A similar result was acquired with the leave extract of Tectona grandis in Togo [20], Justicia secunda Vahl in Benin [21] and I. batatas [22]. The non-anaemic group showed a slight increase in the mean number of red blood cells as observed.

Furthermore, the mean corpuscular haemoglobin concentration $(\mathrm{MCHC})$ and mean corpuscular volume
(MCV) were constants for typing anaemia. MCV reduction showed a significant difference in the untreated group after the administration of phenylhydrazine, signifying microcytosis. This reduction was counteracted at day 14 across the treated groups and day 14 in the untreated anaemic group.

Besides, the compensation was faster with ferrous (iii) hydroxide and I. batatas extract, implying to possible similar mechanisms implicated in erythropoiesis. This result varied with Ogwumike [19] studies in Nigeria who reported a reduction in the MCV when treated with an aqueous extract of Sorghum bicolor leaves. Augmentation of MCV divulges the release of enlarging premature erythrocytes (macrocytes) [23]. However, an increase in $\mathrm{MCHC}$ repeals the comparability of $\mathrm{MCV}$ across experimental groups. Reduced MCHC was also reported by Ogwumike [19] in his experimental model. This decrease in $\mathrm{MCHC}$ reproduced red cells discharge and less haemoglobin inundated (hypochromic). It perhaps could be triggered by the release from macrocytes. This, therefore, indicated that $I$. batatas extract just as ferrous (iii) hydroxide improves the quantity of juvenile cells in blood swiftly due to subsequent triggers from haematopoiesis and their immature release into bloodstream preceding to the end of their differentiation [Figs. 2, 3, 4, 5, 6, 7]. Another study discovered improved osmotic red blood cells resistance with Justicia secunda Vahl extracts in Benin [21] and Tectona grandis in Togo [20]. The extract displayed no consequence on the thrombocyte lineage 
Table 1 Acute toxicological effect of Ipomoea batatas L. on Swiss mice

\begin{tabular}{|c|c|c|c|c|}
\hline Groups & Doses (mg/kg) & No. of lethality & $\%$ mortality & Behavioural changes \\
\hline Control & DW & $0 / 5$ & 0 & No adverse effect \\
\hline 1. batatas & 10 & $0 / 5$ & 0 & No adverse effect \\
\hline I.batatas & 100 & $0 / 5$ & 0 & No adverse effect \\
\hline I.batatas & 1000 & $0 / 5$ & 0 & No adverse effect \\
\hline I.batatas & 1600 & $0 / 5$ & 0 & No adverse effect \\
\hline 1. batatas & 2900 & $0 / 5$ & 0 & No adverse effect \\
\hline 1. batatas & 5000 & $0 / 5$ & 0 & No adverse effect \\
\hline
\end{tabular}

Table 2 Effect of Ipomoea batatas L. on the body mass index across the various groups

\begin{tabular}{|c|c|c|c|c|}
\hline Days/groups & Control & $\begin{array}{l}125 \mathrm{mg} / \mathrm{kg} \text { l. batatas } \\
\mathrm{MEAN} \pm \text { SEM }\end{array}$ & $\begin{array}{l}250 \mathrm{mg} / \mathrm{kg} \text { l. batatas } \\
\mathrm{MEAN} \pm \text { SEM }\end{array}$ & $\begin{array}{l}500 \mathrm{mg} / \\
\mathrm{kg} / . \text { batatas } \\
\text { MEAN } \pm \text { SEM }\end{array}$ \\
\hline Days 7 & $183.75 \pm 3.15$ & $225 \pm 42.48$ & $181.25 \pm 14.77$ & $161.25 \pm 8.26$ \\
\hline Days 14 & $189.5 \pm 4.33$ & $250 \pm 39.53$ & $192.75 \pm 11.61$ & $177.5 \pm 2.5$ \\
\hline Days 28 & $192.75 \pm 48.02$ & $257.25 \pm 54.1$ & $204.75 \pm 44.18$ & $199.0 \pm 48.43$ \\
\hline
\end{tabular}

Values are mean $\pm S E M ; n=5$

via an exhibition of its effects not widen across all haematopoietic heredity.

The results of the study also showed that bone marrow of the treated groups has stimulating effects on the myeloid/erythroid ratio (20: 40, 21.7: 43.4 and 23. 3:46.6) when compared with the untreated group at 15.0: 25.0 and 25: 50 (M: E ratio), while normal control bone marrow, which could be liable for red blood cells stimulation in bone marrow, was considerable [Fig. 8]. Improvement in myeloid-erythroid cells ratio was observed in more in $500 \mathrm{mg} / \mathrm{kg} \mathrm{n}$-hexane extract. These findings agreed with the earlier study by Nostro et al., [1]; Noda et al.[7]; Bratosin et al.[8] on the significant alteration and increase in red blood cells morphology and myeloid-erythroid cells of the bone marrow. The finding enhances the property of the plant extract in the synthesis of normal red blood cells [23], and the mechanism of action could be triggered by the function of erythropoietin cells in the kidney to promote bone marrow myeloid-erythroid cells production of red blood cells [23].

No significant increase in the acute toxicological adverse effect, which could perhaps be endorsed for the acute toxicity of n-hexane extract of Ipomoea batatas L., was observed [Tables 1 and 2]. Moreover, negative behavioural changes were the significant observations showed in clinical physical signs [24]. Our study did not observe any notable changes. It is remarkable to note that in the duration of the study, there was no mortality recorded. Therefore, it is suggested that a higher lethal dose $\left(\mathrm{LD}_{50}\right)$ of n-hexane extract that was greater than $500 \mathrm{mg} / \mathrm{kg}$ can be administered since no death was observed from the doses administered, as shown in Table 1. These findings are absent with earlier studies [19] that reported no death at higher doses. More so, the administration of I. batatas leaf extracts showed no significant alteration in the body weights of the affected rats (Table 2), thereby suggesting no adverse effect on the metabolic actions of treated rats with the plant extract.

Similarly, no significant difference in tissue histology of rats in treated and control groups $(P>0.05)$ was observed. Implications from these results show that $\mathrm{n}$-hexane extracts of sweet potatoes showed no toxicity as observed from the safety doses $(125 \mathrm{mg}-500 \mathrm{mg} /$ $\mathrm{kg}$ body weight). Sweet potato leaf extract in this study [25] may be attributed to fewer leaf options as medicinal benefits of I. batatas. Conversely, further and advanced studies will be desirable to suitably review the toxicity of I. batatas products with chronic toxicity studies.

\section{Conclusions}

In conclusion, the study showed that leaf extracts of Ipomoea batatas L. possess antioxidative, anti-anaemic properties and is safe even at higher doses at $500 \mathrm{mg} /$ $\mathrm{kg}$. Our study also provides the fundamental preclinical order of sequence in drug development related to antianaemic and antioxidative herbal therapy in Nigeria.

\section{Abbreviations}

DPPH: Diphenyl-1-picrylhydrazyl; EDTA: Ethylenediaminetetraacetic acid; LD: Lethal dose; RBC: Red blood cells; HGB: Haemoglobin; HCT: Haematocrit; MCV: 
Mean corpuscular volume; MCH: Mean corpuscular haemoglobin; MCHC: Mean corpuscular haemoglobin concentration.

\section{Acknowledgements}

Our sincere and deep appreciation goes to Mr. Dialect and Mr. Ehigie of the Department of Haematology University of Benin Teaching Hospital, Mr. Odega Kelvin and Mrs. Queen Okoro of the Department of Morbid Anatomy, University of Benin Teaching Hospital, and they did slides preparation and interpretation.

\section{Authors' contributions}

The research work was carried out by 'BOG' under the supervision of prof. MI. Both authors read and approved the final manuscript.

\section{Funding}

Not applicable for this section.

\section{Availability of data and materials}

Data were obtained from this research study and statistically analysed as shown in Tables and Figures Materials such as chemicals, drugs, kits and animals where ordered from necessary stores within and out the country.

\section{Declarations}

\section{Ethical approval and consent to participate}

All procedures using animals obtained the approval of Life Sciences Institutional Animal Ethical Committee, University of Benin with LS17101 ethical number.

\section{Consent for publication}

Not applicable for this section.

\section{Competing interests}

No competing interest.

Received: 21 August 2021 Accepted: 12 October 2021

Published online: 02 November 2021

\section{References}

1. Nostro A, Germanò MP, D’angelo V, Marino A, Cannatelli MA (2000) Extraction methods and bioautography for medicinal plant antimicrobial activity evaluation. Lett Appl Microbiol 30:379-384

2. Philpott M, Ferguson LR, Gould KS, Harris PJ (2009) Anthocyanin-containing compounds occur in the periderm cell walls of the storage roots of sweet potato (Ipomoea balatas). J Plant Physiol 166(10):1112-1117. https://doi.org/10.1016/J.JPLPH.2008.12.007

3. Konczak-Islam I, Yoshimoto Y, Hou D, Terahara N, Yamakawa O (2003) Potential chemopreventive properties of anthocyanin-rich aqueous extracts from in vitro produced tissue of sweet potato. J Agric Food Chem 51:5916-5922

4. Rabah IO, Hou DX, Komine SI, Fujii M (2004) Potential chemopreventive properties of the extract from baked sweet potato (Ipomoea batatas lam. Cv. Koganesengan). J Agric Food Chem 51:5916-5922

5. Suda I, Oki T, Masuda M, Kobayashi M, Nishiba Y, Furuta S (2003) Physiological functionality of purple-fleshed sweet potatoes containing anthocyanins and their utilization in food. Jpn Agric Res Quart 37:167-173

6. Dini I, Tenore GC, Dini A (2009) Saponins in Ipomoea batatas tuber: isolation, characterization, quantification and antioxidant properties. Food Chem 113:411-419
7. Noda N, Horiuchi Y (2008) The resin glycosides from the sweet potato (Ipomoea batatas L. LAM.). Chem Pharmacol Bull (Tokyo) 56 (11):16071610. https://doi.org/10.1248/cpb.56.1607.

8. Bratosin D, Mazurier J, Tissier JP, Estaquier J, Huart JJ, Ameisen JC, Aminoff D, Montreuil J (2008) Cellular and molecular mechanisms of senescent erythrocyte phagocytosis by macrophages. A review Biochimie 80(2):122-156

9. Lippi G, Schena F, Salvagno GL, Aloe R, Banfi G, Guidi GC (2012) Footstrike haemolysis after a 60-km ultramarathon. Blood Transfus 10(3):377383. https://doi.org/10.2450/2012.0167-11 (Epub 2012 May 17)

10. Ogwumike $\mathrm{OO}$ (2002) Hemopoietic effect of aqueous extract of the leaf sheath of Sorghum bicolor in albinos rats. Afr J Biom Res 5:69-71

11. Lorke DA (1983) new approach to practical acute toxicity testing. Arch Toxicol 54(1):275-287

12. OECD (Organization for Economic Cooperation and Development) (2008a) Acute oral toxicity - up and down procedure In OECD Guidelines for testing chemicals No. 425. OECD, Paris, France.

13. OECD (Organization for Economic Cooperation and Development) (2008b) Repeated dose oral toxicity test method. In: OECD Guidelines for testing of chemicals, No. 407. OECD, Paris, France.

14. Drury RAB, Wallinton EA (2013) Carletons histological technique, 16th edn. Oxford University Press, London

15. Fasidi DA, Gbeassor M, Vovor A, Eklu-Gadegbeku K, Aklikokon K, Agbonon A (2008) Effect of Tectona grandis on phenyl hydrazine-induced anaemia in rats. Fitoterapia 79(5):332-336

16. Moswa JL, Kapanda N, Mungende DM, Okitolonda W, Mayangi M, Mihigo S, Mbale K (2005) Plant as a vital source of iron for the treatment of anaemia: the case of Justiciasecunda. $11^{\text {th }}$ NARECA Symposium Book of Proceedings. Madagascar, Antananarivo 132-135p.

17. Akinkugbe OF (1991) Anaemia: the perils of plenty. Clin Pharmaceut Herb Med 8:15-15

18. Adeyemi OS, Akanji MA, Ekanem JT (2010) Anti-anaemic properties of the ethanolic extracts of Psidium guajava in Trypanosoma brucei brucei infected rats. Research Journal pharmacology 4(3):74-77. ISSN 1815-9362.

19. Ogwumike $\mathrm{OO}$ (2002) Hemopoietic effect of aqueous extract of the leaf sheath of Sorghum bicolor in albino rats. Afr J Biom Res 5:69-71

20. Fauchet $R$, Ifrah N, Blanchet O, Dautel M (1995) Collection biologie medicale hematologie (2nd ed.). Condé-sur-Noireau (France), pp437.

21. Gbenou JD, Tossou R, Dansou P, Fossou M, Moudachirou M (2006) Etude des propriétés antianémiques de Justicia secunda Vahl (acanthaceae) chez les rats de souche wistar. Pharm Med Trad Afr 14:45-54

22. Huang DJ, Lin CD, Chen HJ, Lin YH (2004) Antioxidant and anti-proliferative activities of sweet potato (Ipomoea batatas (L.) Lam "Tainong 57") constituents. Bot Bull Acad Sin 45:179-186

23. Leong LP, Shui G (2002) An investigation of the antitoxic capacity of fruit in Singapore markets. Food Chem 76:69-75. https://doi.org/10.1016/ S0308-8146(01)00251-5

24. Naughton BA, Moore E, Bush ME, Lapin DM, Domfest BS (1995) Hemostatic alterations associated with phenylhydrazine - induced haemolytic anaemia. Eur J Clin Invest 25:722-727

25. Diallo A, Gbeassor M, Vovor A, Eklu-Gadegbeku K, Aklikokou K, Agbonon A (2008) Effect of Tectona grandis on phenylhydrazine induced anemia in rats. Fitoterapia 79:332-336. https://doi.org/10.1016/j.fitote.2008.02.005

\section{Publisher's Note}

Springer Nature remains neutral with regard to jurisdictional claims in published maps and institutional affiliations. 